\title{
The 28th International Geological Congress, Washington, 1989
}

\author{
U.S. Geological Survey, 950 National Center, Reston, VA 20192-0001, USA. E-mail: cnelson@ usgs.gov
}

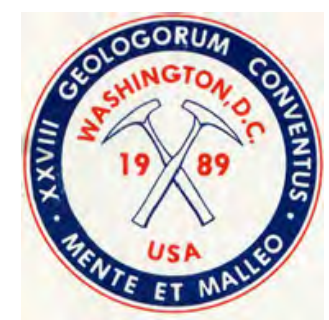

The 28th International Geological Congress (IGC) met from 9 to 19 August 1989 in Washington, District of Columbia, the site of the 5th (1891) and 16th (1933) IGCs. More than 6,000 persons, from the United States of America (USA) and 103 other countries, came to Washington for the 28th IGC, thirteen of them having previously attended the 16th IGC. The U.S. Geological Survey and the U.S. National Academy of Sciences acted as the principal hosts, in cooperation with thirty scientific societies and seven industrial organizations. As sponsors, 115 organizations and five individuals provided financial support. The fourteen themes of the 360 scientific and technical sessions, and ninety poster-paper sessions, included aspects of the dynamic Earth in space and time, mathematical geology, and comparative planetology. Two half-day colloquia of invited presentations provided a planetary perspective on the Apollo lunar-landing program and the Earth's natural resources. Invited speakers in a late-afternoon series of plenary sessions gave forty-five-minute overviews of the international programs for the decade of natural disaster reduction, geological correlation, geosphere-biosphere, lithosphere, ocean drilling, and sedimentary geology. Two hundred and thirty-three exhibitors, from twentysix countries, presented displays. Other activities included a Youth Congress, evening lectures and receptions, local tours, institutional exhibits, and an allmember evening picnic on the Mall on 18 July. Innovations included poster-paper sessions, an extensive program of short courses and workshops, the Gazette ( $a$ daily newspaper), and a field trip to Antarctica (in January 1989). One hundred and three additional field excursions, held before, during, or after the 28th IGC and each with a guidebook, took participants to geologically diverse parts of the USA, Antarctica, the Bahamas, and the Turks and Caicos Islands. The Congress's general-proceedings volume appeared in 1990. Surplus moneys from the Congress provided a foundation for a '28th IGC Fund', managed by the Geological Society of America Foundation, principally to support attendance at future IGCs and the preparation of the next IGC held in the USA.

\section{Prologue: The Invitation, 1980-1984}

The 26th International Geological Congress (IGC) had convened in Paris on 7 July 1980 (Sangnier and Degouy, 1981; Gohau, 2006). Its Council and General Assembly approved an invitation from the Union of Soviet Socialist Republics (USSR, now the Commonwealth of Independent States) to hold the 27th IGC in Moscow in 1984. The Council also endorsed the tentative offer by Vincent E. McKelvey, Chairman of the United States of America (USA) delegation and former Director (1971-1978) of the U.S. Geological Survey (USGS), "to host the 28th Session in the USA in 1988 or 1989" (Hanshaw, 1990, p. 3). In October, H. William Menard, who succeeded McKelvey as USGS Director in 1978, urged Charles L. Drake (Hanshaw, 1998), of Dartmouth College and Chairman of the U.S. National Academy of Sciences-National Research Council's (NAS-NRC) U.S. National Committee on Geology (USNC/G), to accept USA sponsorship of the 28th IGC. Menard promised the same "USGS support" (Hanshaw, 1990, p. 3) that the agency provided in Washington, District of Columbia (D.C.), for the 5th IGC in 1891 (Nelson, 2006) and 16th IGC in 1933 (Nelson, 2009).

By "June 1981, the USNC/G turned down the 1988 date" (Hanshaw, 1990, p. 3) because the Geological Society of America (GSA) planned to celebrate its centennial in 1988 at the annual meeting scheduled for Denver. Instead, the 28th IGC would convene in 1989. Drake and Linn Hoover (USGS), the USNC/G's Secretary, determined during the summer of 1981 that Japan would not be able to host the 28th IGC. In "July 1982, the USNC/G approved July 1989 for the

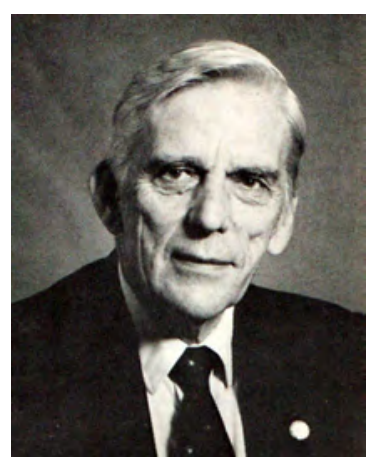

Charles Lum Drake (1924-1997), President of the 28th IGC 
proposed U.S. invitation", Drake "was informally appointed President of the 28th IGC and Chairman of the Preparatory Committee," and he began "negotiations with the Washington Convention Center and nearby hotels" in D.C. (ibid.). In October 1982, NAS President Frank Press asked Yevgeny A. Kozlovsky, Minister of Geology of the USSR and the 27th IGC's President, "to present the USA's formal invitation to host the 28th Session in July 1989" (Ibid.). In November 1982, Kozlovsky agreed to do so. In June and December 1983, Drake and Hoover agreed to serve, respectively, as the 28th IGC's President and Secretary General. Hoover began expanding Drake's preliminary contacts with service organizations.

The 27th IGC met in Moscow from 4 to 14 August 1984, led by Kozlovsky, who also chaired the meeting's Steering Committee, and Nikita A. Bogdanov, Moscow State University and the Institute of the Lithosphere's Director, as Secretary General (Kozlovsky, Bogdanov and Menner, 1987; Milanovsky, 2004). Dallas L. Peck, who succeeded Menard as USGS Director in 1981, led the USA delegation. At the initial meeting of the 27th IGC's Council on 4 August, Peck asked the Council, on behalf of the USNC/G, to request the General Assembly's approval of the USA's invitation for the 28th IGC. The Council unanimously supported Peck's request (Kozlovsky, Bogdanov, and Menner, 1987). On 13 August, the Council discussed invitations from Japan and the People's Republic of China (PRC) to host the 29th IGC, but it reached no decision pending the arrival of preliminary field-excursion programs from both nations (ibid.).

On 14 August, the Council voted to accept the USA's invitation to hold the 28th IGC in Washington, waiving, as was done for the 16th IGC, the rule that required IGCs to convene every three or four years. At the 27th IGC's Closing Ceremony, Kozlovsky and Howard R. Gould (Exxon, now Exxon-Mobil), Drake's successor as Chairman of the USNC/G, formally announced the Council's and the General Assembly's decisions (ibid.).

\section{Organization, 1984-1989}

The 27th IGC's Steering Committee, chaired by Kozlovsky, met in Paris on February 5, 1985, to fix the site and time of the 28th IGC, to be co-hosted by the NAS and the USGS. John A. Reinemund (USGS; Gryc and Terman, 2003), Treasurer of the International Union of Geological Sciences (IUGS), participated as one of the Committee's six other members. Gould and Hoover attended as observers and as members of the 28th IGC's Preparatory (later Organizing) Committee. Previous IGCs had emphasized the geology of continents and their fold belts. The Steering Committee now wished to focus future IGCs on active continental margins, volcanic-island arcs, and ocean basins (Kozlovsky, Bogdanov and Menner, 1987; International Geological Congress, 28th, 1987). The Steering Committee accepted the proposal of the Japanese National Committee on Geology to convene the 29th IGC in Japan in 1992. The Committee also recommended holding the 30th IGC in the PRC, if that country's Geological Society reissued its invitation and the 29th IGC's Council accepted it (Kozlovsky, Bogdanov, and Menner, 1987).

But three days later, a heart attack took Hoover's life while he and his USA and Canadian colleagues waited on a plane preparing to leave Orly Airport for an IUGS meeting in Rabat (Brown, 1987). To succeed Hoover, Peck, who would lead the USA delegation to the 28th IGC, asked Drake to appoint the geohydrologist Bruce B. Hanshaw, the USGS's Assistant Director for Research, as the new
Secretary General (Hanshaw, 1990; Medlin, Peck, Keith, Robinson and Jones, 2000).

Hanshaw took office and began work on 4 March 1985, aided by Hoover's careful preparations and complete files. The American Association of Petroleum Geologists (AAPG) informally contracted to provide for all logistical services to the Congress, which "became a legal corporation in February 1985" (Hanshaw, 1990, p. 3). Its Bureau met initially on 24 April to fix the Organizing Committee's membership and select chairpersons for the topical committees. In September, the U.S. Internal Revenue Service gave the 28th IGC Corporation tax-exempt status. The 28th ICG and the AAPG signed a formal contract before the end of 1985 .

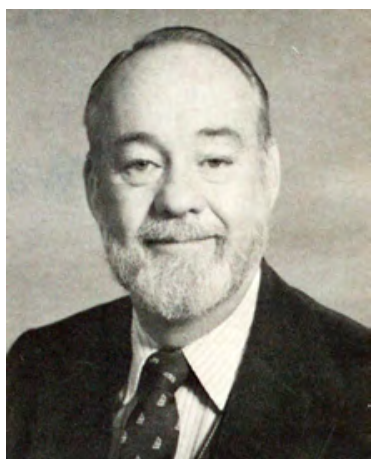

Bruce Busser Hanshaw (1930-1998), Secretary General, 28th IGC.

The Congress appointed an Honorary President, sixteen Honorary Vice-Presidents, and forty-five Honorary Members. The planning and activities depended on the work of its twelve-member Bureau, twentyseven topical Committees, a forty-member Committee of Advisors, thirty-seven organizational hosts, 120 organizational and individual sponsors, and a twelve-member IGC Steering Committee. George H. W. Bush, President of the USA, served as the meeting's honorary president. Drake led the Bureau, aided by Hanshaw, Deputy Secretary General Jack H. Medlin (USGS), and Treasurer William C. Prinz (USGS). The Bureau's seven topical vice-presidents included: Robin Brett (USGS), Scientific and Technical Sessions; Maria Louisa Crawford (Bryn Mawr), Workshops and Short Courses; William L. Fisher (Director, Texas Bureau of Economic Geology), Institutional Participation; Howard Gould, Finances; Charles D. Masters (USGS), Operations; John C. Reed Jr (USGS), Field Trips; and Leon T. Silver (California Institute of Technology), Program. Richard S. Fiske (National Museum of Natural History [NMNH], Smithsonian Institution) and E-an Zen (USGS) served as counselors. Michel T. Halbouty (of Halbouty Energy) and Dallas Peck co-chaired the Committee of Advisors. The USGS and the NAS were the principal hosts, aided by twenty-nine scientific societies and seven industrial organizations. IUGS president William W. Hutchison (Canada), IUGS Secretary General Richard Sindig-Larsen (Geological Survey of Norway), Kozlovsky, Bogdanov, Drake, Hanshaw, IUGS PastPresident Eugen Seibold (Federal Republic of Germany), and five officers of recent IGCs formed the Steering Committee.

Three new programs provided financial and related aid to enable young scientists, especially those from developing countries, to attend the Congress. After William Hutchison died in 1987, the IUGS established the Hutchison Young Scientist Foundation to enable awardees to participate in the IGCs and other IUGS-sponsored meetings; the Foundation sponsored three persons at the 28th IGC. 


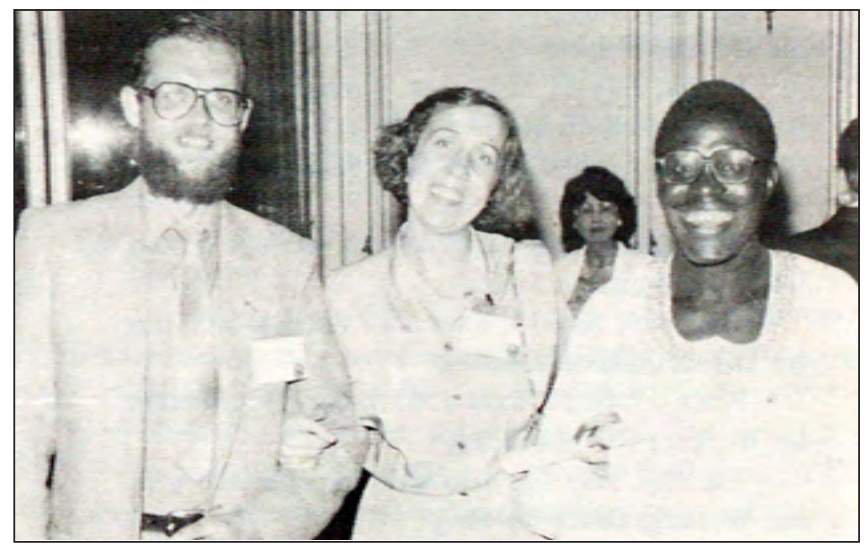

Hutchison Young Scientist Awardees, 28th IGC (from left to right): Witold Zuchiewicz (Poland), Maria Aguirre-Urreta (Argentina) and Barth Ekwueme (Nigeria).

Applications for two other support programs were due by 1 August 1988. The USA's Geohost Program, directed by Rosalind T. Helz (USGS) and George R. Helz (University of Maryland) waived the registration fees for the IGC and for one field trip or short course (up to US\$600*) and provided twelve nights free lodging at the George Washington University dormitory. A separate Bed and Breakfast Program, using lodgings in private homes, extended GeoHost. The Office of the Division of Earth Sciences (Paris) of the United Nations' Educational, Scientific, and Cultural Organization provided \$50,000$\$ 60,000$ for air-fares and the remainder for per-diem expenses-for a Travel Grant Program. Travel Grants covered ten to fifty percent of air-travel costs, provided $\$ 200$ per diem, and benefited from 'noshow' funds. The GeoHost and Travel Grant Programs received "more than 500 applications" and the Selection Committee "ultimately sponsored 79 registrants from 43 countries", or "almost $1.5 \%$ of the total registration" (Hanshaw, 1990, p. 25).

In January 1987, the Organizing Committee began sending more than 100,000 copies of the First Circular (International Geological Congress, 28th, 1987) to interested persons, including all of the members of the 27th IGC, scientific societies, government agencies, and industrial organizations worldwide. Receipt of the enclosed questionnaire was requested by 15 May, but later extended to 15 September. Deposits for the 204 proposed field trips and fifty-three proposed short courses and workshops were requested by September 1988 and the remaining sums were due by April 1989. Abstracts of papers for the fourteen categories of proposed scientific and technical sessions and poster-paper sessions were due by 1 October 1988 (later extended to February 1989). To reduce costs, the Organizing Committee decided not to publish the papers presented at the 28th IGC; instead, authors were encouraged to publish them in scientific journals. The Congress would issue a three-volume set of expanded abstracts of "up to 900 words in length and include line drawings, tables of data, and equations if desired" (Hanshaw, 1990, p. 8). Full payment of pre-registrations for participating, accompanying, student, and non-attending members was due not later than June 1989.

In January 1988, the Second Circular (International Geological Congress, 28th, 1989a) went to the more than 5,000 persons who returned the First Circular's questionnaire and indicated that they would be accompanied by nearly 2,500 other adults and about 760

*Hereafter the \$ symbol is used to represent U.S. dollars. children. Most of the remainder of the Second Circular's 20,000 mailed copies went as reminders to scientific and other organizations. Registration rates of $\$ 50$ for students, $\$ 100$ for accompanying members, $\$ 125$ for nonattending members, $\$ 150$ for senior participating members, and $\$ 200$ for participating members were fixed until 1 February. Thereafter, they would rise by $\$ 25$ during the period 1 February to 1 May and by an equal amount after May 1. The American Geophysical Union (AGU) agreed to publish the Guidebooks and provide fifty free copies for each field trip in return for authority to prepare and sell bound volumes of topically grouped Guidebooks. Penelope M. Hanshaw (USGS and Bruce Hanshaw's wife), appointed Co-Chairman of the Field Trip Committee, edited the Guidebooks for the now 132 field trips-forty-eight pre-meeting, twenty-seven during the meeting, and fifty-seven after the meetingunder the general supervision of John M. Aaron (USGS), Chairman of the Publications Committee. The AGU agreed to publish these Guidebooks, even if some of the trips had to be cancelled, and also agreed to publish the notes for most of the thirty-three short courses. The Second Circular also described seventeen workshops, a nineteenactivity program for accompanying members, and a ten-activity Youth Congress.

Scientific and technical sessions, poster-paper sessions, exhibits, and the scientific theater's screenings would be held in the Washington Convention Center (WCC), bounded by H Street and New York Avenue and 9th and 11th Streets, Northwest (N.W.) in D.C. The adjacent Ramada Renaissance Techworld and the Grand Hyatt

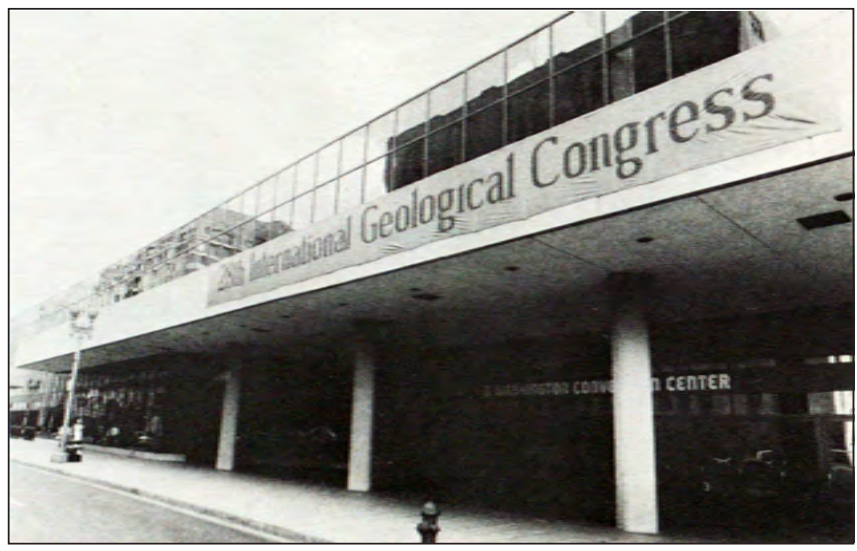

The 28th ICC's venue: The Washington [D.C.] Convention Center (WCC); view looking northwest from 9th Street, N.W., in 1989]. This WCC subsequently was demolished and a new and larger WCC built to the north on the long rectangle of ground between 7 th and 9th Streets and $K$ and $N$ Streets, N.W.

Washington served as the 28th IGC's co-headquarters. Accommodations there and at the other eight hotels in Northwest D.C., all within walking distance of the WCC, ranged from $\$ 68-\$ 190$ for singles, $\$ 68-\$ 215$ for doubles, or $\$ 650-\$ 1,200$ for ten-day packages. Dormitory rooms were available at the American, Georgetown, and George Washington Universities. The Washington Metrorail, an underground transit system begun in 1969, was opened in 1976. By 1989, Metrorail's Blue, Orange, Red, and Yellow Lines, some still expanding, facilitated travel within D.C. and also served its National Airport and the nearby portions of Maryland and Virginia. The surface Metrobus system and taxis supplemented Metrorail; other buses and taxis served Dulles International Airport in northern Virginia. 
Attendees would encounter D.C.'s usually hot and humid summer, but did benefit from the extensive development of central airconditioning in public buildings since World War II (International Geological Congress, 28th, 1989a). To save funds, the Congress did not operate a shuttle-bus service.

Copies of the Third Circular (International Geological Congress, 28th, 1989b) went out to all registrants early in April 1989, as announcements and notices continued to appear in Episodes, Geotimes, and the publications of other professional organizations and societies. The number of registrations received (actually far less than those promised) for field trips by the deadline of 1 February required reducing their number to nineteen before the 28th IGC and twenty-eight after the meeting.

The Program Committee, co-chaired by Robin Brett and Brian H. Mason (NMNH), received about 3,700 abstracts of proposed papers. Eighty-eight percent of these were accepted and fitted into thematic symposiums; those remaining were arranged by subject matter. Each symposium had two conveners-one from the USA and the other from another country. Late abstracts were wait-listed; all but about fifty received places on the program.

\section{Finances}

Howard Gould supervised three units: Budget, led by Priestly Toulmin III (USGS) and then William Prinz as Treasurer; Finances, managed by Norman H. Foster and Michael Johnson (both independents at Denver); and Audit, directed by Robert L. Fuchs (GSA). Estimates during October 1985 to February 1989 of the moneys needed for a successful IGC ranged from $\$ 4.4$ million to $\$ 6.9$ million and averaged $\$ 5.3$ million. Expenses incurred by the 28th IGC's Bureau were offset by the arrangements for publication. The final revised budget of February 1989 projected an income of $\$ 5$ million and expenditures of $\$ 4.9$ million. The Bureau estimated that it would need to raise $\$ 1.8$ million, but later lowered that figure to $\$ 1.63$ million. One hundred and five federal, state, academic, and industrial organizations, and five private individuals pledged and provided $\$ 1.55$ million by 1 April 1989 . The total funds topped $\$ 1.63$ million by the time the Congress convened. This sum included $\$ 230,000$ from the USGS, $\$ 55,000$ in an interest-free loan from the GSA, \$10,000 from the Gulf Coast Association of Geological Societies, and \$5,500 from the Houston Geological Society. The AAPG deferred payment for its convention services and the AGU printed the field trip guides and most of the short-course notes.

\section{Registration}

Members began registering at the WCC on 8 July and received their materials, which included the Program (International Geological Congress, 28th, 1989c) and the three volumes of Abstracts (International Geological Congress, 28th, 1989d). The registration office was open twelve hours each day from 9 to 18 July. Penelope Hanshaw and Joan W. Hoover (Chevy Chase, Maryland, and Linn Hoover's wife) led the Member Services Committee. The Information Booth was open from 8 a.m to 5 p.m. each day, its thirty-person staff being supplemented by volunteers from the International Visitors Information Service (IVIS) of Washington, D.C., who spoke Chinese, French, German, Italian, Japanese, Russian, or Spanish. Attendees who spoke other languages were able to draw on the IVIS language bank, available by telephone 24 hours each day. A total of 5,786 persons registered for the 28th IGC and 5,645 of them attended the meeting. They were accompanied by 399 relatives and friends, and eighty-five children.

\section{Communications}

In addition to the regular news releases prepared for members of the press, a twenty-person staff, using scanners and Apple desktop publishing, worked each night to prepare the free daily, four-page Congress newspaper (the Gazette). The eight issues (two with special inserts) were available at 7 a.m. each morning of the Congress, to present to news of activities and significant subjects of research and publication.

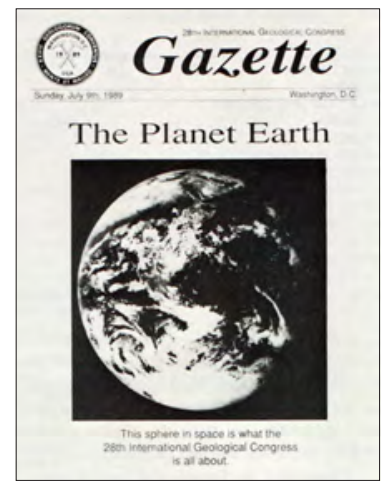

The Gazette, the Congress's daily newspaper.

\section{Opening Ceremony and First General Assembly}

The doors of Hall A opened at 2:30 p.m. on 9 July. The U.S. Marine Corps Band ('The President's Own') played a musical prelude until 3 p.m., when Drake, on behalf of the Organizing Committee, welcomed the participants to the Opening Ceremony. Halbouty read a message of welcome, encouragement, and best wishes for a successful meeting from President George H. W. Bush, and introduced the Under Secretary of the Interior, Frank Bracken, who represented Interior Secretary Manuel Lujan while the Secretary was in New Mexico. Bracken presented greetings and good wishes from Lujan and promised continued strong support by the Department by Interior. Peck emphasized the continuing revolution in the earth sciences that provided new techniques and tools for research and the international cooperation that led to an increased understanding of the Earth and its hazards and resources, made ever more important by the parallel growth in human population. The NAS President, Frank Press, echoed the value of the internationalization of science for reasons both pragmatic and humanitarian.

At 4:45 p.m., Yevgeny Kozlovsky opened the meeting of the 28th IGC's General Assembly and passed to the elections of Drake and Bruce Hanshaw. Drake requested and received ratification of the activities during the Council's meeting that morning, including accepting the Japanese delegates' invitation to hold the 29th IGC in Kyoto in 1992. He noted the invitation from Chen Yuqi D. (PRC) to hold the 30th IGC in Beijing in 1996, which would be submitted for formal acceptance at the 29th IGC. James M. Harrison (Ottawa), the former Director of the Geological Survey of Canada, first President of the IUGS, and former Director of Unesco's Division of Earth 
Sciences, recalled the contributions to IUGS by its late President William Hutchison. Umberto G. Cordani (University of Sao Paulo), President of the IUGS, stressed the importance of the geosciences in education, government planning and policy making, and international collaboration. Vladimir Sibrava, Director of Unesco's Division of Earth Sciences, Paris, also promoted international cooperation in science. Bruce Hanshaw noted that the \$2 million contributed to the Congress by its more than 110 sponsors had enabled the Organizing Committee to minimize costs; without this aid, registrations might have risen to $\$ 750$ each. Drake closed the General Assembly's meeting at about 5 p.m. and invited its participants to a Reception that followed immediately in Hall B (Exhibits).

\section{Scientific and Technical Program}

From 8:30 a.m. to noon and from 1:30 to 5:00 p.m. each day (except for July 15 and 16) the Congress held the 232 sessions of its fourteen-topic scientific and technical program in Hall A. The attendees delivered about 3,100 oral presentations (in English only) in 360 sessions and displayed 550 poster papers in ninety sessions. Some of the accepted papers by the twenty-five percent of authors who were 'no shows' were replaced by reserve papers, of which two were scheduled for each ten-paper session. The sessions included the following topics:

\author{
General \\ Comparative Planetology \\ Crystalline Crust in Space and Time \\ Environmental Geology \\ Extraterrestrial Geology \\ Geological Education \\ History of Geology \\ Mantle and Core in Space and Time \\ Mathematical Geology \\ Mineralogy \\ Paleontology \\ Resources: Oil, Gas, and Mineral Deposits \\ Sedimentary Crust in Space and Time \\ Surface and Near-Surface Processes \\ Tectonic Processes
}

\section{Colloquia and Plenary Sessions}

Two colloquia were held in Hall A as the only scientific program on two mornings. Invited papers of general interest were presented in the sessions on 'World Natural Resources', chaired on 10 July by Eugen Seibold, William Fisher, and Brian J. Skinner (Yale University), and 'The Twentieth Anniversary of the Apollo Moon Landing-A Planetary Perspective' on 19 July, chaired by Valery L. Barsukov (Institute of Geochemistry, Moscow), James W. Head (Brown University) and Dallas Peck.

Invited speakers in a late-afternoon series of six plenary sessions gave forty-five-minute overviews of five principal and ongoing international efforts. Anthony Y. Naldrett (University of Toronto) and Brian Skinner reviewed the Geological Correlation Program in two parts on 10 and 18 July. Karl Fuchs (Geological Institute, Karlsruhe) assessed the International Lithosphere Program on 11 July. Frank Press discussed the International Decade of Natural Disaster Reduction on 12 July. Robert N. Ginsburg (University of Miami) evaluated the Global Sedimentary Geology Program on 13 July. Philip D. Rabinowitz (Ocean Drilling Program [ODP] and Texas A\&M University) reviewed on 14 July the achievements by and plans for the ODP as the Deep Sea Drilling Project's successor. The ODP was supported by funds from the NSF, the ten-member Joint Oceanographic Institutions for Deep Earth Sampling, and Australia, Canada, the European Science Foundation, the Federal Republic of Germany, France, Japan, and the United Kingdom. William S. Fyfe (University of Western Ontario) evaluated the progress of the International Geosphere-Biosphere Program on 17 July.

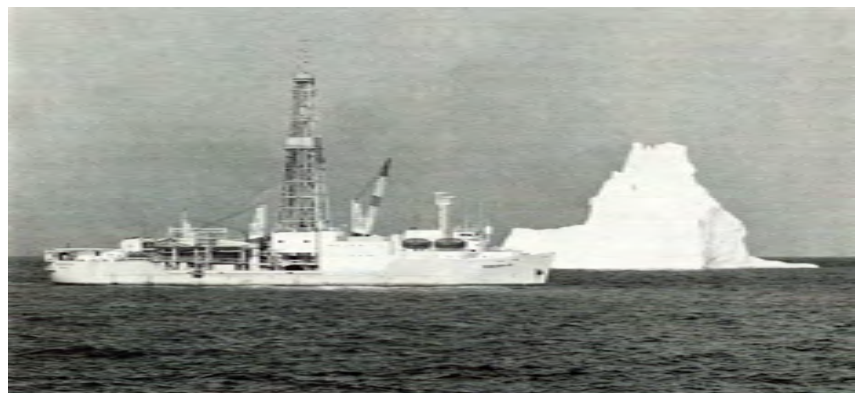

SEDCO/BP 471, was completed for commercial ocean drilling in 1978. The ship, 143.3 meters long, 21.3 meters wide, and with a draft of 7.3 meters and a displacement of 16,906 tonnes, was later converted for use by the Joint Oceanographic Institutions for Deep Earth Sampling (JOIDES) and renamed Resolution. This photograph was taken in Baffin Bay during Leg 105 of the Ocean Drilling Program.

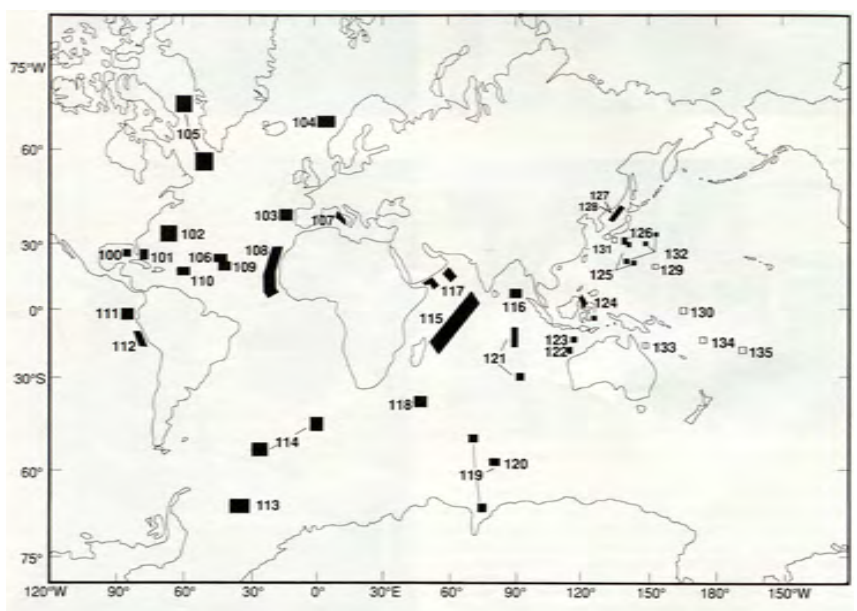

Sites drilled by the JOIDES Resolution during January 1985 November 1989 on Legs 100-135 of the Ocean Drilling Program.

\section{The Spendiarov Prize}

The Leonid A. Spendiarov Prize honors "a young and talented Russian geologist of Armenian origin" who attended the opening ceremony of the 7th IGC in St Petersburg in 1897 but died that evening from injuries earlier sustained in an accident while in "the Caucasus region in connection with the preparation of a post-Congress excursion" (Milanovsky, 2004, p. 101). Spendiarov's father convinced Academician Aleksandr P. Karpinsky (Russia, later USSR), the President of the 7th IGC, and its Council, to accept the Prize to be funded by the between-meetings' interest from a bank fund established by the family. Karpinsky was the first recipient of the Spendiarov 
Prize at the 8th IGC in Paris in 1900. At the 14th IGC in Madrid in 1926, the Soviet delegation transferred custody of the fund to the IGC. Since 1956, the Prize "traditionally has been presented to an outstanding geoscientist from the host country". It specifically honors "advanced scientific contributions and activities in different fields of geology and international scientific cooperation" (Hanshaw, 1990, p. 31).

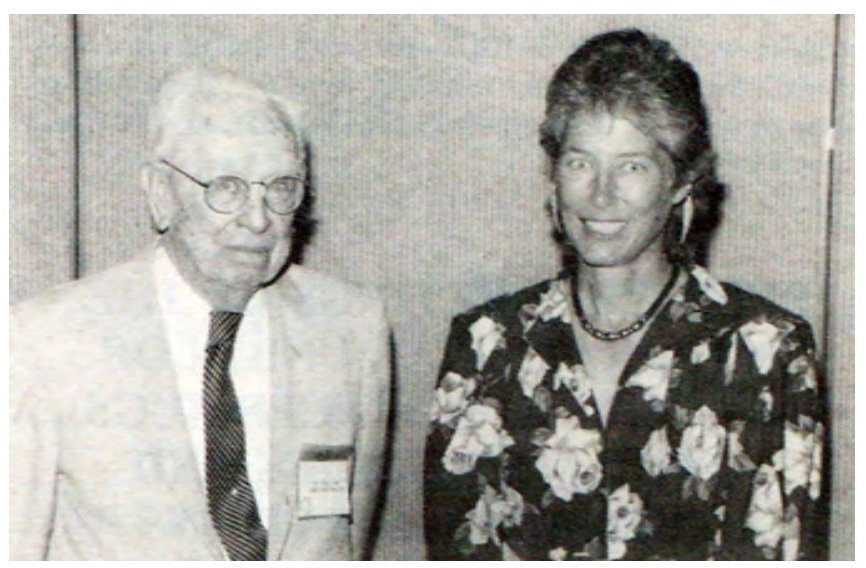

Thomas Brennan Nolan (1901-1992, at left) and Susan Werner Kieffer (b. 1942, at right), recipients of the Spendiarov Prize.

On 13 July, at the 28th IGC Council's second meeting, Academician Boris S. Sokolov (USSR) presented the diploma and premium of the eighteenth Spendiarov Prize to Susan W. Kieffer (USGS). (She later transferred the award's honorarium to two elementary-school teachers in Flagstaff and Los Angeles.) The Prize honored Kieffer's contributions to "knowledge of the Earth and the planets" and her research "in fields varying from volcanology and planetology to thermodynamics and river hydraulics" (International Geological Congress, 28th, 1989c, p. 22). Thomas B. Nolan (USGS, retired; Nelson, 2002), who received the Prize's seventh award at the 16th IGC in 1933, was at the 1989 ceremony to add his congratulations to those Kieffer received. Kieffer joined the USGS as a mineral physicist and volcanologist in 1978 but left in 1990 for posts in academia. She was elected to the NAS in 1986.

\section{Educational Outreach}

Priscilla C. Grew (Minnesota Geological Survey) and M. Gordon Wolman (Johns Hopkins University), Co-Chairmen of the Public Education Committee, Leon Silver, and their colleagues arranged for a number of varied educational activities. The Smithsonian Institution hosted an evening series of three public lectures at the NMNH's Baird Auditorium. In this series, Eugene M. Shoemaker (USGS) assessed 'Solar System Roulette: Consequences of Large-Body Impacts for Life on Earth' on 11 July, Aleksandr T. Basilevsky (Vernadsky Institute of Geochemistry) reviewed 'Venus: Recent Discoveries' on 13 July, and John F. Dewey (Oxford University) gave an account of recent ideas on the 'India and Eurasia Collision and the Origin of Tibet' on 17 July. The Smithsonian and the USGS co-sponsored at the NMNH an exhibit on 'Active Volcanoes', curated by Richard Fiske. The Smithsonian Libraries' Dibner Library presented an exhibit on 'Stratigraphy's Golden Age-Murchison and his Silurian System'. The Library of Congress's Geography and Maps Division hosted an exhibit and catalogue, by the Division's Assistant Chief (later Chief) Ralph E. Ehrenberg, which illustrated the 'History of Geological
Mapping and Maps'. The Science Theater committee, chaired by William H. Mathews III (Lamar University), operating continuously in part of the WCC, showed films and video-tapes of general and specific interest in the earth sciences.

Eighty-five persons between the ages of thirteen and nineteen, from the USA and eighteen other countries, accompanied their parents to the Congress and registered for the Youth Congress and its ten specific activities. Fifty-four of the participants, provided with bus transportation (where needed) and box lunches, participated in organized visits to the NMNH (Y1, Y3) and its Naturalist Center (Y2), the National Air and Space Museum's Center for Earth and Planetary Studies (Y4), the National Aeronautics and Space Administration's Goddard Space Flight Center (Y5), the Potomac River Gorge (Y6), the Calvert Cliffs fossil sites (Y7), Hemlock Overlook County Park (Y8), Prince William County Park (Y9), and the Skyline and Luray Caverns (Y10) during day-long and briefer trips. Local site visits also included the Carnegie Institution of Washington's Geophysical Laboratory, George Washington University's Geology Department, the National Geographic Society's Cartographic Section, the National Institute of Standards and Technology, the NMNH's Mineral Sciences Section, the USGS, and the U.S. Naval Observatory.

\section{Exhibits}

Drawing on his experiences with the Circum-Pacific Mapping Project, John Reinemund and his associates arranged for more than 5,000 square meters in 499 spaces for exhibits in the WCC's Hall B. There were 233 exhibitors, from twenty-six countries, occupied 477 spaces each of nine square meters; of these 173 were commercial displays. The three exhibit groups-Educational, General, and USA Government Agencies_-generated an income of $\$ 415,828$, of which $\$ 278,820$ represented surplus funds (Hanshaw, 1990, p. 21).

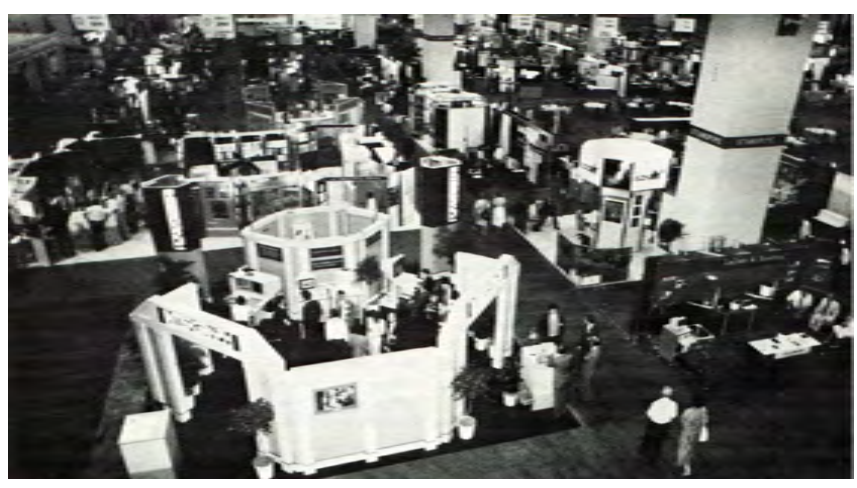

The 28th IGC's exhibits venue: Hall B of the Washington Convention Center.

\section{Entertainment}

The accompanying members enjoyed nineteen different cultural, historical, scenic, and social events, spread over ten days and conducted by contract tour guides. These activities included half-day trips (X1-X8) in and around D.C.; weekend day tours (V1-V7) to Annapolis, Baltimore, Charlottesville, Gettysburg, Harper's FerryAntietam, Potomac Mills, and Williamsburg; and evening events (Z1Z3) (two in Washington and a concert at Wolf Trap in Virginia); and the all-member evening picnic on the Mall on 18 July. 


\section{Field Trips}

Penelope Hanshaw, Robert B. Mixon (USGS), John Reed Jr, Juergen Reinhardt (USGS), and their colleagues arranged 104 field trips of four to ten days duration, most of which were held in the two weeks before or in the two weeks following the Congress. The premeeting trips ended in locations offering easy travel to D.C.; the postmeeting trips ended in locations facilitating easy departures for the foreign participants. These trips attracted 1,276 paid attendees; 208 participated in the pre-meeting trips, 670 in those held during the meeting, and 398 in the post-meeting trips.

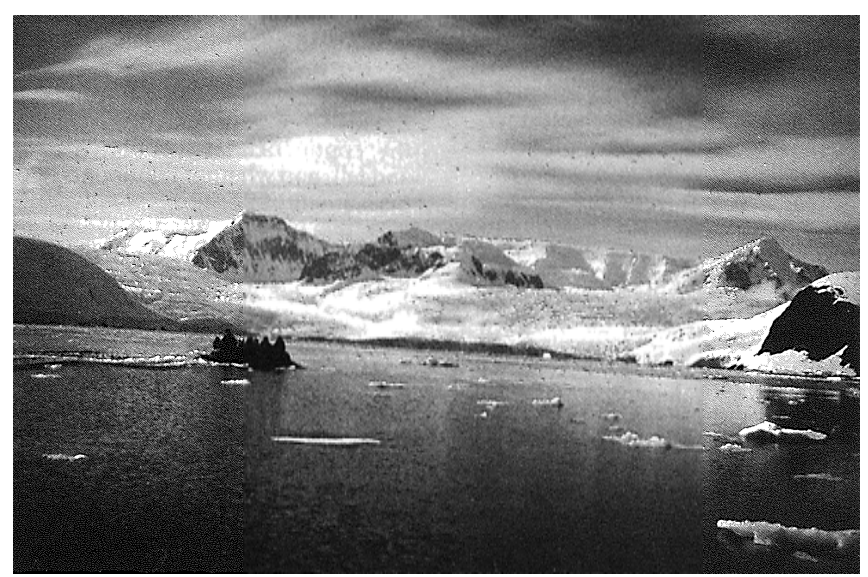

T180 party in a 'zodiac' (inflatable boat) off the west coast of Graham Land, Antarctic Peninsula, in January 1989 (Dalziel, 1989, top fig., p. 13).

These field trips actually began with a voyage to Antarctica from 1 January to 4 February 1989 led by Ian W. D. Dalziel of the University of Texas (Field Trip T180, 'The Tectonics of the Scotia Arc'). Supported by the U.S. National Science Foundation and the IUGS, it reviewed past work and made suggestions for future studies. Twentyfour earth scientists from eight countries sailed from Punta Arenas in the U.S. Antarctic Research Vessel Polar Duke through the waters of the Tierra del Fuego and across the Drake Passage to visit significant sites on the South Shetlands and on the northernmost part of the Antarctic Peninsula.

The other forty-eight pre-meeting field trips included ones in:

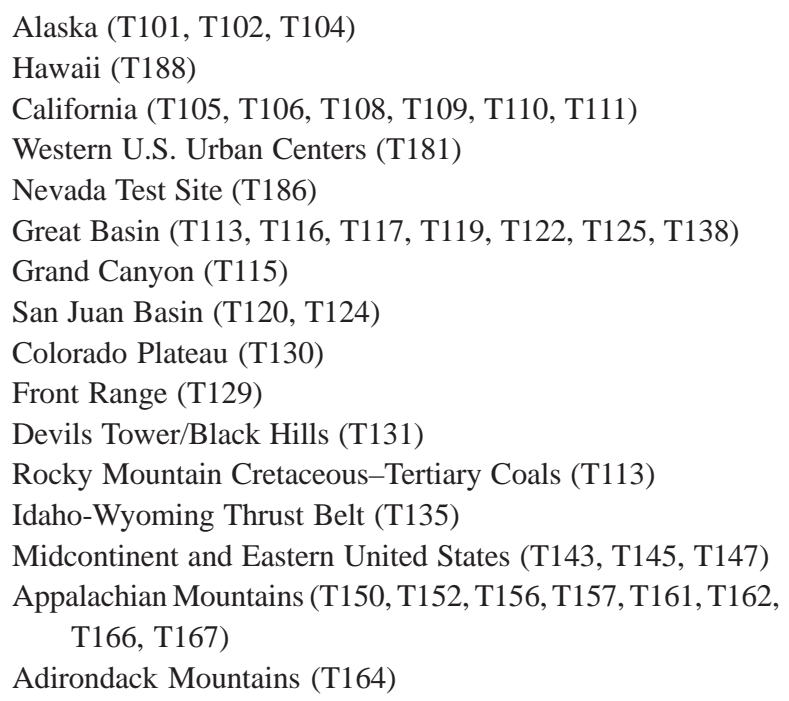

Boston to Buffalo in the Footsteps of Amos Eaton and Edward Hitchcock (T169)

Atlantic and Gulf Coastal and Coastal Plain (T171, T172, T173, 176, T178)

Florida Aquifer System (T185)

San Salvador Island, Bahamas (T175)

Remote Sensing in Exploration Geology (T182)

The twenty-eight field trips held during the meeting included those in:

Virginia (T201, T202, T203, T207, T213, T221, T236, T244)

Maryland (T204, T206, T211, T214, T217, T226, T231, T233, T241, T243)

Virginia and Maryland (T216, T218, T219, T227)

Washington, D.C. (T208, T209, T234, T235)

Washington, D.C. and Maryland (T232)

Pennsylvania (T242)

The forty-seven post-meeting field trips included:

Alaska (T301)

Hawaii (T304; same as T188)

Northern Cascades Range (T307)

Columbia River (T382)

California (T308, T309, T381)

Grand Canyon (T315, same as T115)

Texas (T317, T376)

New Mexico (T320)

Arizona (T338)

Yellowstone/Grand Tetons/Middle Rocky Mountains (T328)

Wyoming (T332)

Montana (T334, T338, T346)

Vermont (T362)

New York City (T361)

Appalachians (T351, T354, T363, T368)

Exuma Islands, Bahamas (T373)

Turks and Cocos Islands, British West Indies (T374)

Florida (T375)

Physical and Hydrologic-Flow Properties of Fractures (T385)

The AGU published Guidebooks for all the field-trips advertised in the Second Circular and also combined and republished them in twenty-five volumes under thirteen titles:

Coal and Hydrocarbon Resources of North America (2 volumes)

Coastal and Marine Geology of the United States (1 v.)

Environmental, Engineering, and Urban Geology in the United States (2 v.)

Geology of Grand Canyon, Northern Arizona (with Colorado River Guides, 2 v.)

Glacial Geology and Geomorphology (2 v.)

Mesozoic/Cenozoic Vertebrate Paleontology: Classic Localities, Contemporary Approaches (1 v.)

Metamorphism and Tectonics of Eastern and Central North America (3 v.) Mineral Deposits of North America (2 v.)

Sedimentation and Basin Analysis in Siliciclastic Rock Sequences (3 v.)

Sedimentation and Stratigraphy of Carbonate Rock Sequences $(2 \mathrm{v}$.

Tectonics of the Scotia Arc, Antarctica (1 v.)

Volcanism and Plutonism of Western North America (2 v.). 


\section{Short Courses and Workshops}

Maria Louisa Crawford, Richard Fiske, E-an Zen, and their colleagues arranged thirty-three Short Courses and seventeen Workshops for the 28th IGC. Limited responses reduced the total held, all on 15 July, to twelve Short Courses and seven Workshops. The instructors for these sessions taught them without receiving honorariums. The AGU published most of the Short Course notes. The Courses were:

Advances in Geostatistics (S34B)

Applications of Personal Computers to Geology (S33B)

Balanced Cross Sections (S28B)

Brines and Evaporites (S13B)

Carbonate Sedimentology and Petrology (S14B)

Coastal Land Loss (S11B)

Geomorphology from Space (S24B)

Glacial-Marine Sedimentation (S35B)

Metamorphic Pressure-Temperature-Time Paths (S29B)

Metazoan Biomineralization: Patterns, Processes, and Evolutionary Trends (S21B)

North American Geology, An Overview (S26B)

Plate Tectonics and Continental Geology (S27B).

The Workshops were:

Acid Deposition (W6B)

Extinctions in the Geologic Record (W11B)

Fossil Crinoids (W12B)

Geological Problems in Radioactive Waste Isolation-A Worldwide Review (W3B)

Geology and Mineralogy of Diamonds (W13B)

Landscape Evolution and Hazards (W4B)

Metamorphic Fluids (W14B).

\section{Second General Assembly and Closing Session}

The second meeting of the General Assembly convened in Hall A at 11:45 a.m. on 19 July. Drake announced the Council's receipt and encouragement of the proposal by Umberto Cordani, speaking for the nine delegates from Argentina, Bolivia, Brazil, Chile, and Peru, to form a consortium of countries and host (as did the Scandinavian countries for the 21st IGC-Norden in 1960) the 31st IGC at a country in South America in 2000. Cordani, Kozlovsky, and Alexander Renwick (Thirsk, England), the 25th IGC's Secretary General, thanked the 28th IGC's Organizing Committee for a successful and rewarding meeting. Sato Tadashi (University of Tsukuba), Chairman of the Organizing Committee for the 29th IGC, invited and encouraged the participants to come to Kyoto in 1992. Drake closed the 28th IGC, comparing the IGCs to the life cycle of the monarch butterflies in his garden. He termed both entities migratory species and noted with pleasure that the IGC's scientific process certainly would repeat itself in Japan in 1992, likely would do so again in Beijing during 1996, and hopefully re-appear in South America in 2000.

\section{Epilogue, 1990}

The 28th IGC's general-proceedings volume, detailing (as noted above) the important organizational and operational lessons learned as an aid to the organizers of future IGCs, appeared in 1990 (Hanshaw, 1990, pp. 12-14). The Washington Congress more than balanced its financial books, despite the large discrepancies between the number of persons interested in the field trips and short courses and workshops and those that actually attended them, which led to the 28th IGC's "only substantial financial loss" (Hanshaw, 1990, p. 6). Organizers used the meeting's financial surplus of $\$ 278,820$ to begin a 28th IGC Fund, managed by the GSA Foundation, principally to support attendance by the 28th IGC's President and Secretary General at future IGCs and the preparation of the next IGC that might be held in the USA.

\section{References}

Brown, R. D., 1987, Memorial to Linn Hoover, 1923-1985: Geological Society of America Memorials, v. 17, 4 pp.

Dalziel, I. W. D., 1989, Field trip launches year of the IGC: Geotimes, v. 34, no. 4 , pp. $10-13$.

Gohau, Gabriel, 2006, The 26th Unternational Geological Congress, Paris, 1980: Episodes, v. 29, pp. 123-127.

Gryc, George and Terman, M. J., 2003, In memoriam-John A. Reinemund (1919-2002): Episodes, v. 26, pp. 47-48.

Hanshaw, B. B., preparer, 1990, General proceedings-28th International Geological Congress, Washington, D.C., U.S.A., July 9-19, 1989: Reston, Va., The [28th International] Congress, $101+[84]$ pp.

Hanshaw, B. B., 1998, Memorial to Charles Lum Drake 1924-1997: Geological Society of America Memorials, v. 29, pp. 33-36.

International Geological Congress, 28th, 1987, First Circular: Washington, D.C, The Congress, $60 \mathrm{pp}$

International Geological Congress, 28th, 1989a, Second Circular: Washington, D.C, The Congress, $85 \mathrm{pp}$.

International Geological Congress, 28th, 1989b, Third Circular: Washington, D.C, The Congress.

International Geological Congress, 28th, 1989c, Program: Washington, D.C, The Congress, $200 \mathrm{pp}$.

International Geological Congress, 28th, 1989d, Abstracts: Washington, D.C, The Congress, 3 v., 264, 767, and 536 pp.

Kozlovsky, E. A., Bogdanov, N. A. and Menner, V. V., eds, 1987, 27th International Geological Congress-General proceedings: Moscow, Vneshtorgizdat, $338 \mathrm{p}$.

Medlin, J. H., Peck, Dallas, Keith, John, Robinson, Eugene and Jones, Blair, 2000, Memorial to Bruce B. Hanshaw 1930-1998: Geological Society of America Memorials, v. 30, pp. 63-66.

Milanovsky, E. E., 2004, Three sessions of the International Geological Congress held in Russia and the USSR [1897, 1937, 1984]: Episodes, v. 27, pp. 101-106.

Nelson, C. M., 2002, Thomas B. Nolan (21 May 1901-2 Aug. 1992), in Betz, Paul, and Carnes, M. C., eds, American National Biography, Supplement 1, pp. 451-453.

Nelson, C. M., 2006, The Fifth International Geological Congress, Washington, 1891: Episodes, v. 29, pp. 279-286.

Nelson, C. M., 2009, The 16th International Geological Congress, Washington, 1933: Episodes, v. 32, pp. 33-40.

Sangnier, Brigitte and Degouy, Michel, eds, 1981, Actes du $26^{\mathrm{e}}$ Congrès Géologique Internationale, Paris-7-17 Juillet 1980: Paris, Gerfau, 330 pp. [in French and English]. 